\title{
Calcium Carbonate Can Be Used to Manage Soilless Substrate pH for Blueberry Production
}

\author{
Michael J. Schreiber and Gerardo H. Nunez *(D) \\ Horticultural Sciences Department, University of Florida, Gainesville, FL 32611, USA; schreiberm@ufl.edu \\ * Correspondence: g.nunez@ufl.edu
}

check for updates

Citation: Schreiber, M.J.; Nunez, G.H. Calcium Carbonate Can Be Used to Manage Soilless Substrate $\mathrm{pH}$ for Blueberry Production. Horticulturae 2021, 7, 74. https://doi.org/ 10.3390/horticulturae7040074

Academic Editors: Nazim Gruda and Juan A. Fernández

Received: 2 March 2021

Accepted: 2 April 2021

Published: 7 April 2021

Publisher's Note: MDPI stays neutral with regard to jurisdictional claims in published maps and institutional affiliations.

Copyright: (c) 2021 by the authors. Licensee MDPI, Basel, Switzerland. This article is an open access article distributed under the terms and conditions of the Creative Commons Attribution (CC BY) license (https:/ / creativecommons.org/licenses/by/ $4.0 /)$.

\begin{abstract}
Blueberry (Vaccinium corymbosum interspecific hybrids) production in soilless substrates is becoming increasingly popular. Soilless substrates have low $\mathrm{pH}$ buffering capacity. Blueberry plants preferentially take up ammonium, which acidifies the rhizosphere. Consequently, soilless substrates where blueberry plants are grown exhibit a tendency to get acidified over time. Agricultural lime $\left(\mathrm{CaCO}_{3}\right)$ is commonly used to raise soil and substrate $\mathrm{pH}$ in other crops, but it is rarely used in blueberry cultivation. We hypothesized that substrate amendment with low rates of agricultural lime increases substrate $\mathrm{pH}$ buffering capacity and provides nutritional cations that can benefit blueberry plants. We tested this hypothesis in a greenhouse experiment with 'Emerald' southern highbush blueberry plants grown in rhizoboxes filled with a 3:1 mix of coconut coir and perlite. We found that substrate amendment with $\mathrm{CaCO}_{3}$ did not cause high $\mathrm{pH}$ stress. This amendment maintained substrate $\mathrm{pH}$ between 5.5 and 6.5 and provided $\mathrm{Ca}$ and $\mathrm{Mg}$ for plant uptake. When blueberry plants were grown in $\mathrm{CaCO}_{3}$-amended substrate and fertigated with low $\mathrm{pH}$ nutrient solution ( $\left.\mathrm{pH} 4.5\right)$, they exhibited greater biomass accumulation than plants grown in unamended substrates. These results suggest that low rates of $\mathrm{CaCO}_{3}$ could be useful for blueberry cultivation in soilless substrates.
\end{abstract}

Keywords: Vaccinium corymbosum; container; ammonium uptake; southern highbush blueberry

\section{Introduction}

Cultivation in containers filled with soilless substrates is rapidly becoming a popular growing system for blueberry (Vaccinium corymbosum interspecific hybrids) production. Soilless substrates based on sphagnum peat moss or coconut coir are generally acidic [1] and have high water holding capacity [2]. These substrate characteristics promote blueberry nutrient uptake and support vigorous growth [3,4]. As this growing system becomes widespread [5], there is a need for research focused on fertilization and management practices for substrate-grown blueberry.

Sphagnum peat moss and coconut coir have low $\mathrm{pH}$ buffering capacity [6,7]. Consequently, pH changes of up to 1 unit per month are not uncommon $[3,4,8,9]$. While blueberry roots exhibit limited ability to change the rhizosphere $\mathrm{pH}$ through $\mathrm{H}^{+}$extrusion [10], ammonium uptake can lead to rapid rhizosphere acidification [11,12]. Considering blueberry growth and $\mathrm{N}$ content are enhanced by ammonium-based fertilization $[11,13]$, substrate acidification appears inevitable in this production system.

Calcitic $\left(\mathrm{CaCO}_{3}\right)$ and dolomitic $\left[\mathrm{CaMg}\left(\mathrm{CO}_{3}\right)_{2}\right]$ lime are commonly used to raise soilless substrate $\mathrm{pH}$, but amendment rates and effects are crop-specific (reviewed in [14]). The carbonate moiety in lime acts as a buffer that maintains the rhizosphere approximately at $\mathrm{pH} 6.4$ [14]. The cations in lime are nutritionally relevant $\mathrm{Ca}$ and $\mathrm{Mg}$. Substrates used for cultivation of other acid-loving plants are routinely amended with lime to limit substrate $\mathrm{pH}$ change $[15,16]$. Nevertheless, the effects of lime amendments in substrate-grown blueberry remain understudied.

Lime is rarely used in soil-based blueberry cultivation because high liming rates can raise soil $\mathrm{pH}$ excessively and cause plant stress. When grown in high $\mathrm{pH}$ soils, blueberry 
plants exhibit nutritional deficiencies, stunted growth, and lower yields [17-19]. Lime is only used in situations where soil $\mathrm{pH}$ is very low to deliver $\mathrm{Ca}$ and $\mathrm{Mg}$ [20]. Hence, lime amendments must be meticulously used to avoid stressing blueberry plants.

This research investigates the effect of substrate amendment with $\mathrm{CaCO}_{3}$ on the substrate $\mathrm{pH}$, growth, and nutrition of southern highbush blueberry. We hypothesized that substrate amendment with low rates of agricultural lime increases substrate $\mathrm{pH}$ buffering capacity and provides nutritional cations that can benefit blueberry plants. We tested this hypothesis in a greenhouse experiment with plants grown in rhizoboxes.

\section{Materials and Methods}

Rooted cuttings of 'Emerald' southern highbush blueberry (SHB; rooting volume $=3 \mathrm{~cm}^{3}$, average dry weight $=1.15 \mathrm{~g}$, average height $=12 \mathrm{~cm}$ ) were acquired from a commercial micropropagation nursery (Agristarts LLC, Apopka, FL, USA) and transplanted to benchtop rhizoboxes as per [21]. Rhizoboxes were built using two $35.56 \mathrm{~cm} \times 35.56 \mathrm{~cm}$ plexiglass panels spaced $1.9 \mathrm{~cm}$ apart using wood inserts. Each rhizobox contained approximately $1.7 \mathrm{~L}$ of substrate and was irrigated or fertigated by two $1.89 \mathrm{l} \cdot \mathrm{h}^{-1}$ pressure-regulating emitters, spaced approximately $15.25 \mathrm{~cm}$ apart. Custom-made rhizobox stands kept roots in the dark at $33^{\circ}$ inclination. There was one plant per rhizobox. Rhizoboxes were used as a tool to study root growth patterns in response to substrate amendment and fertigation $\mathrm{pH}$ treatments.

Rhizoboxes were filled with a 3:1 mixture of coconut coir (SpongEase ${ }^{\mathrm{TM}}$, Enroot Products LLC, Cromwell, CT, USA) and horticultural grade perlite (American Garden Perlite, LLC, Lake Wales, FL, USA) pre-treated to deliver two substrate amendment treatments. In one treatment, substrate was amended with $\mathrm{CaCO}_{3}$ (Garden Lime, Austinville Limestone, Austinville, VA, USA) at a rate of $6.18 \mathrm{Kg} \cdot \mathrm{m}^{-3}$. This rate corresponds to half of the rate used in [22] where lime amendments were used to stress azalea (Rhododendron spp.). In the other treatment, substrate was amended with Ca-containing fertilizer produced from neutralized $\mathrm{CaCO}_{3}$ (Calexin ${ }^{\circledR}$, Miller Chemical \& Fertilizer Corporation, Hanover, PA, USA) at a rate of $100.3 \mathrm{~L} \cdot \mathrm{m}^{-3}$. Guaranteed analysis and product density information were used to calculate a Calexin application rate that delivered the same amount of $\mathrm{Ca}$ as the $\mathrm{CaCO}_{3}$ amendment. Both amendments were incorporated into moist substrate 7 days before transplant.

Fertigation solution $\mathrm{pH}$ was a second variable in the experiment. Plants were fertigated with a solution containing $0.5 \mathrm{mM}\left(\mathrm{NH}_{4}\right)_{2} \mathrm{SO}_{4}, 0.5 \mathrm{mM} \mathrm{K}_{2} \mathrm{PO}_{4}, 1.0 \mathrm{mM} \mathrm{MgSO}_{4}, 0.5 \mathrm{mM}$ $\mathrm{CaCl}_{2}, 0.045 \mathrm{mM} \mathrm{H}_{3} \mathrm{BO}_{3}, 0.01 \mathrm{mM} \mathrm{MnSO}_{4}, 0.01 \mathrm{mM} \mathrm{ZnSO}_{4}$ with $0.3 \mathrm{mM} \mathrm{CuSO}_{4}, 0.2 \mathrm{mM}$ $\mathrm{Na}_{2} \mathrm{MoO}_{4}$, and $45 \mathrm{mM}$ Fe provided as Sequestrene 330 (10\% iron(III)-diethylenetriamine pentaacetic acid) (Becker Underwood, Inc., Ames, IA, USA). Ammonium was the only form of $\mathrm{N}$ provided, in agreement with industry practices [20]. The low $\mathrm{N}$ rate was selected because blueberry microcuttings exhibited ammonium toxicity when fertigated with higher $\mathrm{N}$ rates in a preliminary experiment. Fertigation solution was buffered using $5.0 \mathrm{mM}$ 2-(4-morpholino)-ethane sulfonic acid to $\mathrm{pH} 4.5$ or pH 6.5 using $\mathrm{HCl}$ or $\mathrm{KOH}$. These fertigation $\mathrm{pH}$ treatments are referred to as low $\mathrm{pH}$ and high $\mathrm{pH}$ respectively in relation to fertigation $\mathrm{pH}$ used in previous studies [3]. There were 21 fertigation/irrigation events per week. Each plant received $1.75 \mathrm{~L}$ of fertigation solution (delivered through 7 events) and 3.96 L of irrigation water per week (delivered through 14 events). Fertigation events preceded irrigation events. Fertigation and irrigation volumes were measured with graduated cylinders connected directly to emitters.

Substrate samples were collected at the start (day 0) and end (days 75-77) of the experiment and submitted for analysis at a commercial laboratory (Waters Agricultural Laboratory, Camila, GA, USA). Ca, Mg, and K concentrations in the substrate were determined using inductively coupled plasma mass spectrometry [23]. Cation exchange capacity (CEC) was calculated from $\mathrm{K}, \mathrm{Ca}, \mathrm{Mg}$, and $\mathrm{H}$ concentrations as per [24]. Substrate $\mathrm{pH}$ was measured in a 1:1 substrate:deionized water slurry [25]. 
Substrate $\mathrm{pH}$ and electrical conductivity (EC) were monitored using the pour-through method [26]. Deionized water samples that eluted through the substrate (hereon, leachate) were collected on a weekly basis ( $n=3$ per treatment). Rhizoboxes were removed from the stand and placed vertically on top of plastic trays (one rhizobox per tray) approximately $2 \mathrm{~h}$ after the last fertigation event. Then, $500 \mathrm{~mL}$ of deionized water were slowly poured on top of the substrate. Leachate was collected in the plastic tray for approximately $20 \mathrm{~min}$. Then, leachate volume was measured with a graduate cylinder and $50 \mathrm{~mL}$ aliquots were transported to the laboratory for immediate measurement of leachate $\mathrm{pH}$ (Accumet AP110 Portable pH Meter, Thermo Fisher Scientific, Hampton, NH, USA) and EC (Accumet Excel Conductivity Meter, XL30, Thermo Fisher Scientific, Hampton, NH, USA) using standardized electrodes. In this manuscript and elsewhere [26], it is assumed that leachate $\mathrm{pH}$ and EC represent rhizosphere conditions. Leaf greenness was measured on the youngest fully expanded leaf of each plant using a SPAD-502 meter (Konica Minolta, Inc., Ramsey, NJ, USA).

Rhizoboxes were scanned using a flatbed scanner (LX1100, Seiko Epson Corp., Tokyo, Japan) at a resolution of 1000 dots per inch (dpi). The scanner was held at an inclination of $30^{\circ}$ during scanning to avoid substrate loss. Rhizoboxes were scanned on a weekly basis starting on week 2 of the experiment. Rhizobox images were used to measure root system convex hull area using ImageJ version 1.51 [27]. Convex hull area is the area of the polygon formed by lines connecting the most distal root tips in a plant. Root system spread was computed as the ratio of the convex hull area to root dry weight.

Rhizoboxes were disassembled 75 to 77 days after the start of the experiment. Roots were washed clean of substrate using tap water. A subset of the root systems $(n=4$ per treatment except for $\mathrm{CaCO}_{3}+\mathrm{pH} 6.5$ where one root image was lost due to human error) were scanned floating in water using the transparency unit of the flatbed scanner at 1000 dpi. Images were divided into 5 tiles using ImageJ. Then, total root length was determined using WinRhizo Pro 2013b (Regent Instruments, Quebec, QC, Canada). Organ and whole plant fresh weight were measured. Leaves were laid flat and photographed at a distance of $48.25 \mathrm{~cm}$ from the lens using mobile phone cameras (iPhone 7 and iPhone $X$, Apple Inc., Cupertino, CA, USA) on a white background with a scale bar of known size. Total leaf area was measured using ImageJ. Plant tissues were weighted after drying at $72{ }^{\circ} \mathrm{C}$ for a week. Dry tissue was ground until it passed through a size-20 mesh (sieve opening $=0.841 \mathrm{~mm}$ ). Then, tissue was submitted for elemental analysis at a commercial laboratory (Waters Agricultural Laboratory, Camila, GA, USA).

The experiment was conducted in a greenhouse where average temperature and relative humidity were $22.53{ }^{\circ} \mathrm{C}$ and $70.19 \%$, respectively. The experiment followed a completely randomized design with treatments in a $2 \times 2$ factorial arrangement. There were 10 single-plant replications per amendment $\times \mathrm{pH}$ combination. Unless otherwise stated, $n=10$ per treatment. Treatment effects on biomass accumulation, leaf area, substrate characteristics, elemental content, and root traits were assessed using two-way analysis of variance (R package agricolae, [28]). Where significant effects were identified, pairwise comparisons were made using the least significant difference method. Leachate $\mathrm{pH}$ and EC data were analyzed through linear mixed-effect analysis (R package lme4, [29]). Fertigation solution $\mathrm{pH}$, substrate amendment, and their interaction were considered fixed effects. Repeated measures per plant and week were considered random sources of error. Leachate $\mathrm{pH}$ and EC were response variables analyzed in separate models. Statistical significance was determined by likelihood ratio tests comparing the full model against a model without the effect being investigated. All statistical analyses were conducted in R version 3.6.2 [30]. Data were illustrated using ggplot 2 [31].

\section{Results}

At the start of the experiment, substrates amended with $\mathrm{CaCO}_{3}$ exhibited higher $\mathrm{pH}$, percentage base saturation, $\mathrm{Mg}$ content, and $\mathrm{K}$ content than substrates amended with Calexin (Table 1). Substrate CEC and Ca content were not different between the amend- 
ment treatments. At the end of the experiment, substrate $\mathrm{pH}$ was not different among treatments (Table 2). Substrates amended with $\mathrm{CaCO}_{3}$ exhibited higher $\mathrm{CEC}$, percentage base saturation, $\mathrm{Ca}$ concentration, and $\mathrm{Mg}$ concentration than substrates amended with Calexin. Substrates that were fertigated at $\mathrm{pH} 4.5$ exhibited lower $\mathrm{K}$ concentration than substrates that were fertigated at $\mathrm{pH}$ 6.5. The interaction of substrate amendment and fertigation $\mathrm{pH}$ did not affect substrate characteristics ( $p \geq 0.158)$.

Table 1. Substrate characteristics before transplant. A substrate composed of a 3:1 mixture of coconut coir and perlite was amended with $\mathrm{CaCO}_{3}$ or a Ca-containing fertilizer (Calexin) 7 days before transplanting 'Emerald' southern highbush blueberry.

\begin{tabular}{|c|c|c|c|c|c|c|}
\hline Amendment & $\mathrm{pH}$ & $\begin{array}{l}\text { Cation Exchange Capacity } \\
\text { (meq } 100 \mathrm{~g}^{-1} \text { Substrate) }\end{array}$ & $\begin{array}{c}\text { Base } \\
\text { Saturation (\%) }\end{array}$ & $\begin{array}{c}\mathrm{Ca} \\
\left(\mathrm{mg} \cdot \mathrm{Kg}^{-1}\right)\end{array}$ & $\begin{array}{c}\mathrm{Mg} \\
\left(\mathrm{mg} \cdot \mathrm{Kg}^{-1}\right)\end{array}$ & $\begin{array}{c}\mathrm{K} \\
\left(\mathrm{mg} \cdot \mathrm{Kg}^{-1}\right)\end{array}$ \\
\hline $\mathrm{CaCO}_{3}$ & 6.4 & 9.50 & 71.77 & 932.17 & 158.67 & 325.67 \\
\hline Calexin & 4.4 & 10.97 & 57.27 & 1089.00 & 43.84 & 194.00 \\
\hline$p$ value $\mathrm{z}$ & $<0.001$ & 0.084 & 0.021 & 0.283 & $<0.001$ & 0.009 \\
\hline
\end{tabular}

${ }^{\mathrm{z}}$ Treatments were compared using ANOVA.

Table 2. Substrate characteristics after 75-77 days of growing 'Emerald' southern highbush blueberry with contrasting substrate amendments and fertigation $\mathrm{pH}$.

\begin{tabular}{|c|c|c|c|c|c|c|}
\hline Treatment & Substrate $\mathrm{pH}$ & $\begin{array}{l}\text { Cation Exchange Capacity } \\
\text { (meq } 100 \mathrm{~g}^{-1} \text { Substrate) }\end{array}$ & $\begin{array}{c}\text { Base } \\
\text { Saturation (\%) }\end{array}$ & $\begin{array}{c}\mathrm{Ca} \\
\left(\mathrm{mg} \cdot \mathrm{Kg}^{-1}\right)\end{array}$ & $\begin{array}{c}\mathrm{Mg} \\
\left(\mathrm{mg} \cdot \mathrm{Kg}^{-1}\right)\end{array}$ & $\begin{array}{c}\mathrm{K} \\
\left(\mathrm{mg} \cdot \mathrm{Kg}^{-1}\right)\end{array}$ \\
\hline $\mathrm{CaCO}_{3}$ & 4.9 & 8.05 & 57.38 & 1298.33 & 307.50 & 99.17 \\
\hline Calexin & 4.7 & 6.73 & 34.60 & 601.83 & 169.67 & 95.83 \\
\hline$p$ value $^{\mathrm{z}}$ & 0.094 & 0.009 & $<0.001$ & $<0.001$ & 0.003 & 0.596 \\
\hline pH 6.5 & 4.8 & 7.30 & 48.95 & 958.33 & 248.67 & 164.67 \\
\hline $\mathrm{pH} 4.5$ & 4.8 & 7.48 & 43.03 & 941.83 & 228.50 & 30.33 \\
\hline$p$ value & 0.999 & 0.643 & 0.144 & 0.901 & 0.563 & $<0.001$ \\
\hline
\end{tabular}

${ }^{\mathrm{z}}$ Data were analyzed by two-way ANOVA. The interaction of fertigation $\mathrm{pH}$ and substate amendment did not affect substrate characteristics $(p \geq 0.158)$.

Substrate amendments and fertigation $\mathrm{pH}$ created contrasting leachate $\mathrm{pH}$ and $\mathrm{EC}$ during most of the experiment (Figure 1). Leachate $\mathrm{pH}$ gradually decreased in all treatments $\left(\chi^{2}=11.74, \mathrm{df}=1, p \leq 0.001\right.$, estimate $\left.=-0.42\right)$. Amendment with $\mathrm{CaCO}_{3}\left(\chi^{2}=93.34\right.$, $\mathrm{df}=1, p<0.001)$ and high $\mathrm{pH}$ fertigation $\left(\chi^{2}=28.69, \mathrm{df}=1, p<0.001\right)$ led to high leachate $\mathrm{pH}$. The interaction of substrate amendment and fertigation $\mathrm{pH}$ did not affect leachate $\mathrm{pH}$ $\left(\chi^{2}=2.57, \mathrm{df}=3, p=0.11\right)$. Amendment with $\mathrm{CaCO}_{3}$ led to higher leachate $\mathrm{EC}\left(\chi^{2}=5.26\right.$, $\mathrm{df}=1, p=0.02)$. Fertigation $\mathrm{pH}\left(\chi^{2}=1.13, \mathrm{df}=1, p=0.29\right)$, time $\left(\chi^{2}=0.22, \mathrm{df}=1, p=0.63\right)$, and the interaction of substrate amendment and fertigation $\mathrm{pH}\left(\chi^{2}=7.33, \mathrm{df}=3, p=0.06\right)$ did not affect leachate EC.

Substrate amendments and fertigation $\mathrm{pH}$ affected plant biomass accumulation (Table 3). Plants grown with a combination of Calexin amendment and low $\mathrm{pH}$ fertigation solution exhibited lower cane, leaf, and total dry weight than plants grown with $\mathrm{CaCO}_{3}$ amendments. Within a substrate amendment, fertigation $\mathrm{pH}$ did not affect biomass accumulation. Plants grown in substrates amended with $\mathrm{CaCO}_{3}$ exhibited larger root systems than plants grown in substrates amended with Calexin. Leaf area followed the same trends as leaf dry weight (data not shown). Leaf greenness was not affected by the treatments (average $=24.68, p=0.23$ ). 

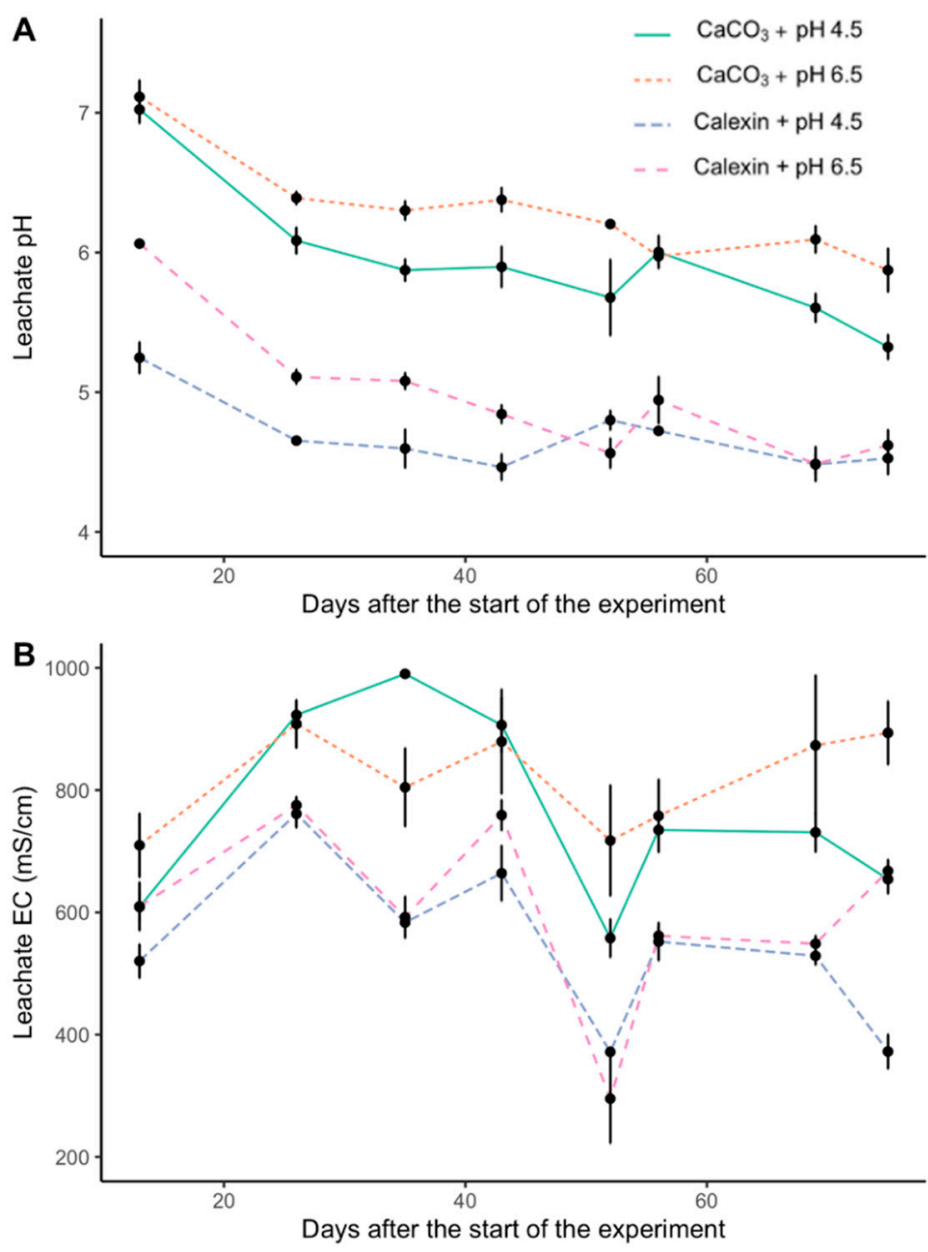

Figure 1. Leachate $\mathrm{pH}(\mathbf{A})$ and electrical conductivity (EC) (B) collected from rhizoboxes where 'Emerald' southern highbush blueberry grew with contrasting substrate amendments $\left(\mathrm{CaCO}_{3}\right.$ or Ca-containing fertilizer Calexin) and fertigation $\mathrm{pH}(\mathrm{pH} 4.5$ and $\mathrm{pH}$ 6.5).

Table 3. Biomass accumulation of 'Emerald' southern highbush blueberry plants grown in rhizoboxes with contrasting substrate amendments and fertigation $\mathrm{pH}$.

\begin{tabular}{|c|c|c|c|c|c|}
\hline Amendment & Fertigation $\mathrm{pH}$ & Root Dry Weight (g) & Cane Dry Weight (g) & Leaf Dry Weight (g) & Total Dry Weight (g) \\
\hline \multirow{2}{*}{$\mathrm{CaCO}_{3}$} & 6.5 & $2.38 \mathrm{a}$ & $3.40 \mathrm{ab}$ & $5.06 \mathrm{ab}$ & $10.84 \mathrm{ab}$ \\
\hline & 4.5 & $2.38 \mathrm{a}$ & $4.91 \mathrm{a}$ & $6.99 \mathrm{a}$ & $14.32 \mathrm{a}$ \\
\hline \multirow{2}{*}{ Calexin } & 6.5 & $1.16 \mathrm{~b}$ & $2.33 \mathrm{bc}$ & $4.01 \mathrm{bc}$ & $7.50 \mathrm{bc}$ \\
\hline & 4.5 & $0.58 \mathrm{~b}$ & $1.33 c$ & $2.59 \mathrm{c}$ & $4.2 \mathrm{c}$ \\
\hline \multicolumn{6}{|c|}{ Effect $^{\mathrm{z}}$} \\
\hline \multicolumn{2}{|c|}{ Amendment } & $<0.001$ & $<0.001$ & $<0.001$ & $<0.001$ \\
\hline \multicolumn{2}{|c|}{ Fertigation $\mathrm{pH}$} & 0.272 & 0.574 & 0.672 & 0.947 \\
\hline \multicolumn{2}{|c|}{ Amendment $\mathrm{x} \mathrm{pH}$} & 0.208 & 0.009 & 0.008 & 0.017 \\
\hline
\end{tabular}

${ }^{\mathrm{z}}$ Data were analyzed by two-way ANOVA. Means followed by the same letter were not significantly different according to Tukey LSD at $\alpha=0.05$.

Substrate amendment and fertigation $\mathrm{pH}$ also affected root system characteristics. Root systems of plants grown with low $\mathrm{pH}$ fertigation and $\mathrm{CaCO}_{3}$ amendments exhibited larger convex hull areas than all other treatment combinations between weeks 3 and 9 (Figure 2A). Root systems of plants grown with low $\mathrm{pH}$ fertigation and Calexin amendments had smaller convex hull area than all other treatments initially (weeks 3 and 4). Plants grown with low $\mathrm{pH}$ fertigation and $\mathrm{CaCO}_{3}$ amendment exhibited higher total root length than plants grown with high $\mathrm{pH}$ fertigation and $\mathrm{CaCO}_{3}$ amendments and plants grown with low $\mathrm{pH}$ fertigation and Calexin (Figure 2B). High $\mathrm{pH}$ fertigation so- 
lution $\left(274.53 \mathrm{~cm}^{2} \cdot \mathrm{g}^{-1}\right.$ vs. $\left.191.66 \mathrm{~cm}^{2} \cdot \mathrm{g}^{-1}\right)$ and $\mathrm{CaCO}_{3}$ amendments $\left(338.97 \mathrm{~cm}^{2} \cdot \mathrm{g}^{-1}\right.$ vs. $\left.127.22 \mathrm{~cm}^{2} \cdot \mathrm{g}^{-1}\right)$ reduced root system spread $(p<0.008$ in all cases). Root system spread was not affected by the interaction of substrate amendment and fertigation solution $\mathrm{pH}(p=0.29)$.
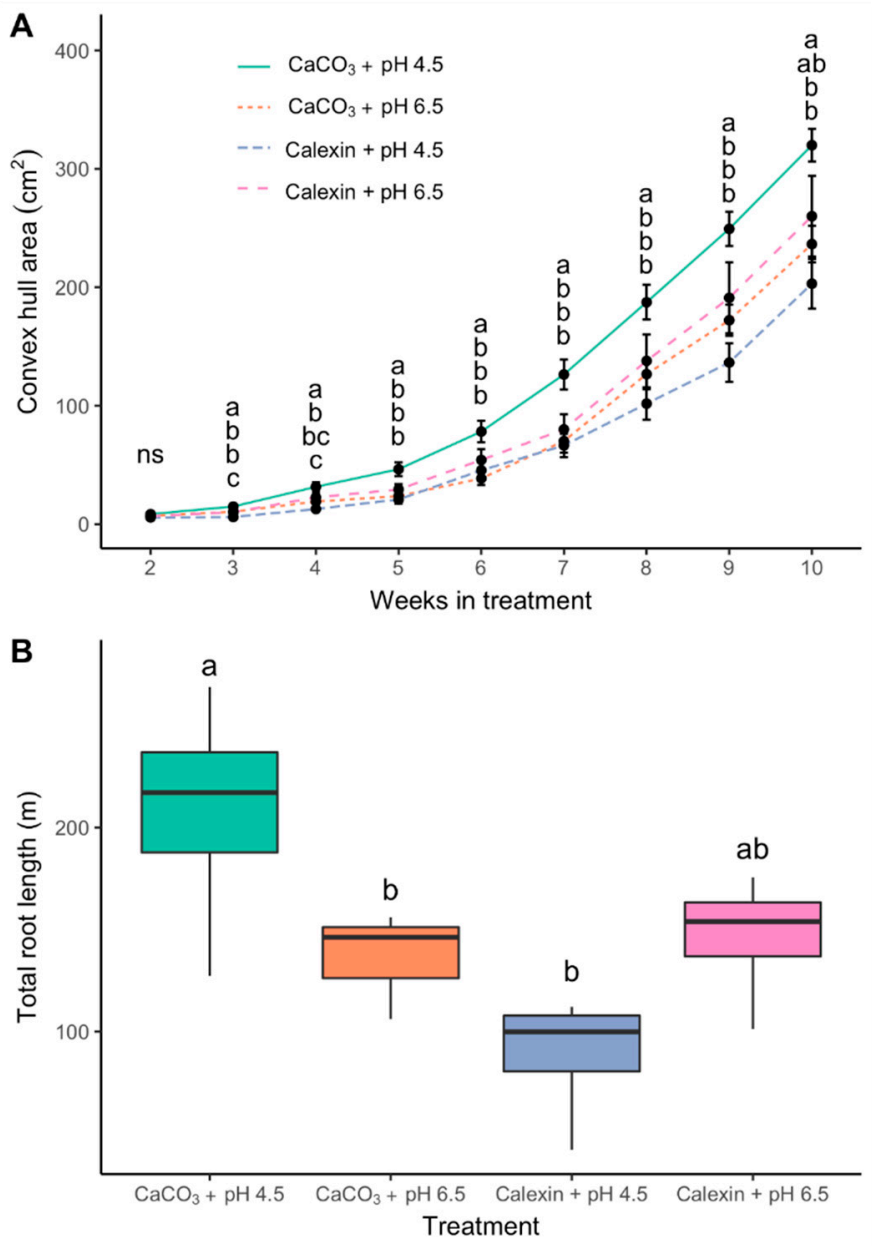

Figure 2. Root system characteristics of 'Emerald' southern highbush blueberry grown with contrasting substrate amendments and fertigation $\mathrm{pH}$. (A) Convex hull area during the treatment period. (B) Total root length after 77 days of cultivation. Means followed by the same letter were not significantly different according to Tukey LSD at $\alpha=0.05$.

Substrate amendment and fertigation $\mathrm{pH}$ affected root and leaf nutrient concentrations (Table S1). High $\mathrm{pH}$ fertigation decreased $\mathrm{N}, \mathrm{Zn}$, and $\mathrm{Cu}$ concentrations and increased $\mathrm{Ca}$ concentration in roots. Substrate amendment with $\mathrm{CaCO}_{3}$ decreased $\mathrm{K}, \mathrm{S}, \mathrm{B}$, and $\mathrm{Cu}$ concentrations and increased $\mathrm{Fe}$ concentrations in roots. Other elements were not affected. The interaction of fertigation $\mathrm{pH}$ and substate amendment did not affect root nutrient concentrations $(p \geq 0.078)$. Plants grown in substrates amended with Calexin and fertigated with low $\mathrm{pH}$ solution exhibited the highest leaf $\mathrm{N}, \mathrm{P}, \mathrm{Ca}, \mathrm{Mg}, \mathrm{S}, \mathrm{Fe}, \mathrm{Zn}$, and $\mathrm{Cu}$ concentrations (Table S2). Plants grown in substrates amended with $\mathrm{CaCO}_{3}$ generally exhibited the lowest leaf concentrations of these elements. Plants grown with low $\mathrm{pH}$ fertigation exhibited higher leaf $\mathrm{Mn}$ concentrations than plants grown with high $\mathrm{pH}$ fertigation. Plants grown in substrates amended with $\mathrm{CaCO}_{3}$ exhibited lower leaf $\mathrm{K}$, $\mathrm{Mn}$, and $\mathrm{B}$. With the exception of $\mathrm{K}$, treatment effects on nutrient concentration did not exhibit the same trends in roots and leaves. 


\section{Discussion}

Soilless substrates have limited $\mathrm{pH}$ buffering capacity [6], which allows large $\mathrm{pH}$ changes over the cultivation period $[3,4,8,9]$. In this experiment, 'Emerald' SHB plants were fertigated with a nutrient solution where ammonium was the only form of $\mathrm{N}$. Ammonium uptake leads to rhizosphere acidification [11,12]. As expected, leachate $\mathrm{pH}$ gradually decreased in all treatments. Similar leachate acidification has been previously observed in experiments with substrate-grown blueberry [4,12] and azalea [32].

$\mathrm{CaCO}_{3}$ is routinely used to raise soil or substrate $\mathrm{pH}$ in other crops [14-16], but not in blueberry. When blueberry and other acid-loving plants are grown in soils or substrates amended with high $\mathrm{CaCO}_{3}$ rates, they exhibit high $\mathrm{pH}$ stress symptoms such as interveinal chlorosis and stunted growth [17-19,33]. In this experiment, $\mathrm{CaCO}_{3}$ in the substrate did not cause high $\mathrm{pH}$ stress in 'Emerald' SHB, probably due to the low rate used. Plants grown in substrates amended with $\mathrm{CaCO}_{3}$ did not exhibit Fe deficiency symptoms either, but leaf Fe concentrations were lower than published recommendations [20]. These results suggest that even though $\mathrm{CaCO}_{3}$ raised substrate $\mathrm{pH}$, the effect was mild enough to avoid causing high $\mathrm{pH}$ stress in 'Emerald' SHB. Further research will be necessary to determine if the $\mathrm{CaCO}_{3}$ rate used here is appropriate for other blueberry varieties.

In this experiment, $\mathrm{CaCO}_{3}$ in the substrate acted as a $\mathrm{pH}$ buffer that partially neutralized $\mathrm{H}^{+}$from ammonium uptake and the fertigation solution, maintaining leachate $\mathrm{pH}$ between $\mathrm{pH} 5.5$ and $\mathrm{pH} 6.5$ for most of the experiment. Additionally, $\mathrm{CaCO}_{3}$ amendment replaced cations from the substrate adhesion sites with $\mathrm{Ca}$ and $\mathrm{Mg}$. The combination of acidic substrate and nutritional cation availability supported vigorous growth above- and below-ground in 'Emerald' SHB, especially when $\mathrm{CaCO}_{3}$ amendment was matched with low $\mathrm{pH}$ fertigation solution.

When the substrate did not contain carbonates, leachate $\mathrm{pH}$ ranged between $\mathrm{pH} 4.5$ and $\mathrm{pH} 5.0$ and almost half of the adhesion sites were occupied by non-nutritional cations. The lack of nutritional cations was likely caused by the abundance of $\mathrm{H}^{+}$and/or Calexin leaching out of the rhizoboxes. These substrate conditions affected shoot and root growth, particularly when the fertigation solution $\mathrm{pH}$ was low. Low $\mathrm{pH}$ increases $\mathrm{Al}$ solubility [34], which can cause $\mathrm{Al}$ toxicity in blueberry [35]. Perlite contains $10-15 \% \mathrm{Al}_{2} \mathrm{O}_{3}$ [36]. Thus, it is possible that $\mathrm{Al}$ toxicity might have affected 'Emerald' SHB growth when substrate $\mathrm{pH}$ was extremely low. Al concentrations in the rhizosphere were not measured in this experiment. Further research will be necessary to establish if $\mathrm{Al}$ toxicity impacted plant responses.

Substrate characteristics affected blueberry root abundance and distribution. $\mathrm{CaCO}_{3}$ amendments increased 'Emerald' SHB root dry weight and, in combination with low $\mathrm{pH}$ fertigation, they led to large root systems that reached most of the substrate in the rhizoboxes. Nevertheless, large root systems were not always better at taking up nutrients. Previous research has shown that $\mathrm{CaCO}_{3}$ can affect nutrient uptake through $\mathrm{pH}$-dependent and $\mathrm{pH}$-independent effects [37]. Thus, fertilization practices might need to be adapted to maintain optimum plant nutrition in substrates amended with $\mathrm{CaCO}_{3}$.

Irrigation water can contain carbonates and bicarbonates (collectively called alkalinity). Alkaline water sources are not uncommon in blueberry production areas [38], but water acidification through sulfuric acid injection or sulfur dioxide generators is routinely used to neutralize alkalinity [39]. Our results suggest that increasing substrate $\mathrm{pH}$ buffering capacity can be beneficial for blueberry. Thus, it is important to recognize the tradeoff between irrigation water $\mathrm{pH}$ and $\mathrm{pH}$ buffering capacity when irrigation water is acidified. Considering the substrate acidification tendency observed here and elsewhere [4,12], it is tempting to speculate on the utility of alkaline water for substrate $\mathrm{pH}$ management. Future research should explore this potential management strategy.

Altogether, our results indicate that substrate amendment with low rates of $\mathrm{CaCO}_{3}$ is a viable tool to increase $\mathrm{pH}$ buffering capacity in coconut coir-based substrates used for blueberry cultivation. $\mathrm{CaCO}_{3}$ neutralized $\mathrm{H}^{+}$and contributed $\mathrm{Ca}$ and $\mathrm{Mg}$ for plant uptake. Access to a weakly acidic substrate with abundant nutritional cations supported vigorous 
growth in 'Emerald' SHB. Further research should evaluate other $\mathrm{CaCO}_{3}$ amendment rates and other blueberry varieties to facilitate decision making when using $\mathrm{CaCO}_{3}$ in substrate-based blueberry cultivation.

Supplementary Materials: The following are available online at https://www.mdpi.com/2311-752 4/7/4/74/s1, Table S1: Nutrient concentrations in roots of 'Emerald' southern highbush blueberry, Table S2: Nutrient concentrations in leaves of 'Emerald' southern highbush blueberry.

Author Contributions: Conceptualization, G.H.N.; methodology, data collection, analysis, and visualization, writing, M.J.S. and G.H.N. All authors have read and agreed to the published version of the manuscript.

Funding: This research received no external funding.

Institutional Review Board Statement: Not applicable.

Informed Consent Statement: Not applicable.

Data Availability Statement: Data presented in this study are available on request from the corresponding author.

Conflicts of Interest: The authors declare no conflict of interest.

\section{References}

1. Konduru, S.; Evans, M.R.; Stamps, R.H. Coconut husk and processing effects on chemical and physical properties of coconut coir dust. HortScience 1999, 34, 88-90. [CrossRef]

2. Abad, M.; Fornes, F.; Carrión, C.; Noguera, V.; Noguera, P.; Maquieira, A.; Puchades, R. Physical properties of various coconut coir dusts compared to peat. HortScience 2005, 40, 2138-2144. [CrossRef]

3. Kingston, P.H.; Scagel, C.F.; Bryla, D.R.; Strik, B.C. Suitability of sphagnum moss, coir, and douglas fir bark as soilless substrates for container production of highbush blueberry. HortScience 2017, 52, 1692-1699. [CrossRef]

4. Kingston, P.H.; Scagel, C.F.; Bryla, D.R.; Strik, B.C. Influence of perlite in peat- and coir-based media on vegetative growth and mineral nutrition of highbush blueberry. HortScience 2020, 55, 658-663. [CrossRef]

5. Fang, Y.; Nunez, G.H.; Silva, M.N.d.; Phillips, D.A.; Munoz, P.R. A review for southern highbush blueberry alternative production systems. Agronomy 2020, 10, 1531. [CrossRef]

6. Kithome, M.; Paul, J.W.; Kannangara, T. Adsorption isotherms of ammonium on coir. Com. Soil Sci. Plant Anal. 1999, 30, $83-95$. [CrossRef]

7. Rippy, J.F.M.; Nelson, P.V. Cation exchange capacity and base saturation variation among Alberta, Canada, moss peats. HortScience 2007, 42, 349-352. [CrossRef]

8. Ramirez, S.V.; Altland, J. Minding Your pHs and Qs. Grow. Talks 2018, 81, 68-69.

9. Taylor, M.D.; Nelson, P.V.; Frantz, J.M. Substrate acidification by geranium: Light effects and phosphorus uptake. J. Am. Soc. Hort. Sci. 2008, 133, 515-520. [CrossRef]

10. Nunez, G.H.; Olmstead, J.W.; Darnell, R.L. Rhizosphere acidification is not part of the strategy I iron deficiency response of Vaccinium arboreum and the Southern Highbush Blueberry. HortScience 2015, 50, 1064-1069. [CrossRef]

11. Imler, C.S.; Arzola, C.I.; Nunez, G.H. Ammonium uptake is the main driver of rhizosphere $\mathrm{pH}$ in southern highbush blueberry. HortScience 2019, 54, 955-959. [CrossRef]

12. Tamir, G.; Zilkah, S.; Dai, N.; Shawahna, R.; Cohen, S.; Bar-Tal, A. Combined effects of $\mathrm{CaCO}_{3}$ and the proportion of N-NH${ }_{4}{ }^{+}$ among the total applied inorganic $\mathrm{N}$ on the growth and mineral uptake of Rabbiteye blueberry. J. Soil Sci. Plant Nutr. 2020, 21, 35-48. [CrossRef]

13. Merhaut, D.J.; Darnell, R.L. Ammonium and nitrate accumulation in containerized southern highbush blueberry plants. HortScience 1995, 30, 1378-1381. [CrossRef]

14. Altland, J.E.; Jeong, K.Y. Dolomitic lime amendment affects pine bark substrate $\mathrm{pH}$, nutrient availability, and plant growth: A review. HortTechnology 2016, 26, 565-573. [CrossRef]

15. Ownley, B.H.; Benson, D.M.; Bilderback, T.E. Physical properties of container media and relation to severity of Phytophthora root rot of rhododendron. J. Am. Soc. Hort. Sci. 1990, 115, 564-570. [CrossRef]

16. Scagel, C.F.; Bi, G.; Fuchigami, L.H.; Regan, R.P. Nutrient uptake and loss by container-grown deciduous and evergreen Rhododendron nursery plants. HortScience 2011, 46, 296-305. [CrossRef]

17. Finn, C.E.; Luby, J.J.; Rosen, C.J.; Ascher, P.D. Blueberry germplasm screening at several soil $\mathrm{pH}$ regimes. I. plant survival and growth. J. Am. Soc. Hort. Sci. 1993, 118, 377-382. [CrossRef]

18. Finn, C.E.; Rosen, C.J.; Luby, J.J.; Ascher, P.D. Blueberry germplasm screening at several soil pH regimes. II. plant nutrient composition. J. Am. Soc. Hort. Sci. 1993, 118, 383-387. [CrossRef] 
19. Jiang, Y.; Zeng, Q.; Wei, J.; Jiang, J.; Li, Y.; Chen, J.; Yu, H. Growth, fruit yield, photosynthetic characteristics, and leaf microelement concentration of two blueberry cultivars under different long-term soil pH treatments. Agronomy 2019, 9, 357. [CrossRef]

20. Hart, J.; Strik, B.; White, L.; Yang, W. Nutrient management for blueberries in Oregon. Or. State Univ. Ext. Serv. 2006, EM8918.

21. Nunez, G.H.; Rodríguez-Armenta, H.P.; Darnell, R.L.; Olmstead, J.W. Toward marker-assisted breeding for root architecture traits in southern highbush blueberry. J. Am. Soc. Hort. Sci. 2016, 141, 414-424. [CrossRef]

22. Susko, A.Q.; Rinehart, T.A.; Bradeen, J.M.; Hokanson, S.C. An evaluation of two seedling phenotyping protocols to assess pH adaptability in deciduous azalea (Rhododendron sect. Pentanthera G. Don). HortScience 2018, 53, 268-274. [CrossRef]

23. US Environmental Protection Agency. Determination of Trace Elements in Waters and Wastes by Inductively Coupled PlasmaMass Spectrometry; Office of Research and Development US Environmental Protection Agency: Cincinnati, OH, USA, 1994; pp. 200.8-1-200.8-51.

24. Reganold, J.P.; Harsh J., B. Expressing cation exchange capacity in milliequivalents per 100 grams and in SI units. J. Agron. Educ. 1985, 14, 84-90. [CrossRef]

25. Schofield, R.K.; Taylor, A.W. The measurement of soil pH. Soil Sci. Soc. Am. J. 1955, 19, 164-167. [CrossRef]

26. Cavins, T.J.; Whipker, B.E.; Fonteno, W.C.; Harden, B.; McCall, I.; Gibson, J.L. Monitoring and Managing Ph and Ec Using the Pourthru Extraction Method; Horticulture Information Leaflet, No. 590; North Carolina State University: Raleigh, NC, USA, 2000.

27. Rueden, C.T.; Schindelin, J.; Hiner, M.C.; DeZonia, B.E.; Walter, A.E.; Arena, E.T.; Eliceiri, K.W. ImageJ2: ImageJ for the next generation of scientific image data. BMC Bioinform. 2017, 18, 529. [CrossRef]

28. De Mendiburu, F. Agricolae: Statistical Procedures for Agricultural Research. Available online: https://www.cran.r-project.org/ web/packages/agricolae/index.html. (accessed on 7 June 2020).

29. Bates, D.; Maechler, M.; Bolker, B.; Walker, S. Fitting linear mixed-effects models using lme4. J. Stat. Softw. 2015, 67, 48. [CrossRef]

30. R Core Team. R: A Language and Environment for Statistical Computing; R Foundation for Statistical Computing: Vienna, Austria, 2017. Available online: http:/ / www.R-project.org/ (accessed on 7 June 2020).

31. Wickham, H. Ggplot2: Elegant Graphics for Data Analysis, 2nd ed.; Springer: Dordrecth, The Netherlands, 2016.

32. Demasi, S.; Caser, M.; Handa, T.; Kobayashi, N.; De Pascale, S.; Scariot, V. Adaptation to iron deficiency and high pH in evergreen azaleas (Rhododendron spp.): Potential resources for breeding. Euphytica 2017, 213, 148. [CrossRef]

33. Turner, A.J.; Arzola, C.I.; Nunez, G.H. High pH Stress Affects Root Morphology and Nutritional Status of Hydroponically Grown Rhododendron (Rhododendron spp.). Plants 2020, 9, 1019. [CrossRef] [PubMed]

34. Driscoll, C.T.; Schecher, W.D. The chemistry of aluminum in the environment. Environ. Geochem. Health 1990, 12, 28-49. [CrossRef]

35. Carcamo, M.P.; Reyes-Díaz, M.; Rengel, Z.; Alberdi, M.; Omena-Garcia, R.P.; Nunes-Nesi, A.; Inostroza-Blancheteau, C. Aluminum stress differentially affects physiological performance and metabolic compounds in cultivars of highbush blueberry. Sci. Rep. 2019, 9, 11275. [CrossRef] [PubMed]

36. Bush, A.L. Construction materials: Lightweight aggregates. In Encyclopedia of Materials: Science and Technology, 2nd ed.; Elsevier: Oxford, UK, 2001. [CrossRef]

37. Brito, L.M.; Monteiro, J.M.; Mourão, I.; Coutinho, J. Organic lettuce growth and nutrient uptake response to lime, compost and rock phosphate. J. Plant Nutr. 2014, 37, 1002-1011. [CrossRef]

38. Smith, E.; Porter, W.; Hawkins, G.; Harris, G., Jr. Blueberry Irrigation Water Quality; University of Georgia Cooperative Extension: Athens, GA, USA, 2016.

39. Bryla, D.R.; Strik, B.C. Nutrient requirements, leaf tissue standards, and new options for fertigation of northern highbush blueberry. HortTechnology 2015, 25, 464-470. [CrossRef] 